This is an Accepted Manuscript of an article published in Perspectives, Studies in Translation Theory and Practice. Volume 24, 2016- Issue 1: Ideology, Censorship and Translation: Past and Present. Received 11 Jan 2015, Accepted 07 May 2015, Published online: 14 Jan 2016,

DOI: $10.1080 / 0907676$ X.2015.1051558

To cite this article:

Raquel Merino-Álvarez (2016) The censorship of theatre translations under Franco: the 1960s, Perspectives, 24:1, 36-47, DOI:

10.1080/0907676X.2015.1051558

The censorship of theatre translations under Franco: the 1960s

Raquel Merino-Álvarez ${ }^{1}$

\title{
Introduction
}

The Spanish censorship archives held in the General Administration Archive (Archivo General de la Administración [AGA], Alcalá de Henares, Madrid) are a rich source of documentation on virtually any aspect of Spanish history from the end of the Civil War (1939) until the decade after the death of Franco (1975-1985). From a cultural point of view, they provide information on publications and theatre or film productions. The enormous amount of data filed by a well-established bureaucratic tradition has helped researchers obtain greater knowledge of Spanish culture through the traces left in the censor's sieve. Censorship was obligatory and universal, and cultural products subject to the censors' scrutiny left an abundant register of information from over forty years.

\footnotetext{
${ }^{1}$ This work was supported by the University of the Basque Country, UPV/EHU, Consolidated Research Group TRALIMA [grant number GIC12/197], the Basque Government [grant number IT728/13]; and the Spanish Ministry for Economy and Competitiveness, MINECO [grant number FFI2012-39012-C04-01T].
} 
Researchers working on the history of Spanish theatre (London, 1997 \& 2012; Muñoz Cáliz, 2005 \& 2008; O'Leary, 2005) have been using the AGA archives to obtain information on Spanish playwrights and plays, making it possible to access richer textual as well as contextual information from this source. Access to censorship documents opens up new ways of dealing with old issues. With respect to translations, the records are at times the only source of reliable information, since historical accounts of theatre in Spanish (staged or published), focused as they are on the 'Spanish', have traditionally ignored the 'foreign' (translated into Spanish) and so an important part of Spanish theatre has habitually been overlooked.

The study of censored translations inevitably leads to a consideration of who the authors of the versions were and what role they played in importing foreign theatre to Spanish stages. From the evidence in the censorship archives, one is faced with a truly hidden story, and a new perspective of the history of Spanish theatre comes to light by focusing on names of Spanish playwrights, stage directors, producers, actors and translators.

Historical accounts of Spanish theatre dwell on authors, directors and actors, producers and theatre groups and venues, with little or no reference to foreign theatre or the work of translators who made productions of foreign plays possible. Even in the more recent and thorough volume edited by Delgado and Gies (2012) the role played by translations and translators is overlooked. 
In this contribution we aim at filling that gap by focusing on foreign theatre translated and performed in the 1960s, presenting the polemical case of E. Albee's Who's afraid of Virginia Woolf?(¿Quién teme a Virginia Woolf?) (1962) translated by Méndez Herrera, a professional translator whose versions of foreign plays were usually at the centre of controversy.

\section{The censorship of theatre translations under Franco}

Censorship was obligatory and universal under Franco's rule: it was applied to all types of cultural production, from printed books and periodicals to stage productions and films. In the case of theatre there was a specific Directorate within the Ministry for Information and Tourism in charge of assessing plays and films (Dirección General de Cinematografía y Teatro) (Gutiérrez Lanza, 2011) and the documents derived from the censorship process are now available at the AGA.

The TRACE (TRAnslations CEnsored, www.ehu.es/trace) project was designed to look specifically at translation in the censorship process (Rabadán, 2000). Researchers who had been investigating the history of (film, prose, poetry, theatre) translations in Spain using traditional sources of information found in the Spanish censorship archives a means of extending their knowledge of Spanish "translated culture" (Santoyo, 1983). More importantly, the archives offered the chance to shed light on obscure and totally unknown areas of that Spanish translated culture. The lists of authors, national and foreign alike, and titles of plays, original and translated, which were duly filed when submitted to the censor by producers, editors or exhibitors, have become a sort of archaeological site 
that may be excavated and studied. The sheer number of records and files makes sampling the archives a hard task but the results of preliminary studies helped establish, in a fairly accurate manner, which authors or plays were imported through translation at the time. The history of theatre translations in Spain, as seen from censorship archives, has been charted by building catalogues of translations and analysing the information in order to select target corpora (Gutiérrez Lanza, 2011; Merino-Álvarez, 2007).

Following a series of TRACE theatre studies (Bandín, 2007 \& 2011; Merino-Álvarez, 2007; Pérez López de Heredia, 2004 \& 2005), specific corpora have been identified and studied using selection criteria derived from the analysis of catalogues of translations compiled from censorship archives. Quantitative methods have been combined with qualitative studies "on selected sets of cases" derived from the analysis of the information held in the catalogues (Merino-Álvarez, 2012, p. 126). At first the focus was on the most representative authors for a specific source country (U.S., Britain and Ireland), language (English) or period; but subsequently also on the topics deemed 'dangerous' by censors. For example, the polemical issue of adultery has been studied through the compilation and analysis of a corpus of translations and adaptations of Graham Greene's The Complaisant Lover (Merino-Álvarez 2012, pp. 133134). The play's stance on sexual morality challenged the 'open' 
censorship policy ${ }^{2}$ of the 1960s: a six-year long censorship process, fraught with difficulties, resulted in a successful 1968 premiere which proved that Greene's theatrical trajectory in Spain was not "effete" (London, 1997, p. 63).

A study on how the topic of homosexuality entered Spanish stages through translations has traced the issue back to 1950, when Tennessee Williams' Streetcar Named Desire was first filed as a censorship record. William's play, translated into Spanish by José Méndez Herrera, seems to be the first of a trend of translations of plays by foreign playwrights ( $E$. Albee, M. Anderson, M. Crowley and P. Shaffer) that helped introduce topics barred for native playwrights (Merino-Álvarez, 2010, p. 154).

The findings of research done on censorship archives show that even under the so-called official open policy of the 1960s, elaborate negotiations between censors and producers or directors were needed, especially over sensitive topics. Moral sexuality or the equally pernicious issue of foul language were very often at the centre of such negotiations. The case of Edward Albee's Who's afraid of Virginia Woolf?, translated by José Méndez Herrera, is paradigmatic in this respect.

\footnotetext{
${ }^{2}$ Between 1962 and 1969 decisions taken by the new team at the Directorate General for Cinema and Theatre (Ministry for Information and Tourism) under Minister Fraga Iribarne were "more permissive and tolerant than under his predecessors" (Gutiérrez-Lanza, 2011 p. 305). Muñoz-Cáliz (2005) refers to the 1960 s policy of 'opening up' from within the Ministry that contrasted with previous stricter positions under minister Arias Salgado (1950-1962) and the subsequent return to ultra-Catholic positions with Sánchez Bella (1969-1973).
} 


\section{The role of professional translators in Spanish theatre censorship}

In the world of theatre, translation is usually an invisible process that is taken for granted or overlooked. When asked about this aspect of their activity, writers, directors or actors, even those who put their name to adaptations, seem to consider the process of translation as the first necessary step, albeit not as important as the actual writing or rewriting and adaptation (Merino-Álvarez, 1994). Translation, as the process of rendering a text from one language to another, when mentioned, if at all, seems to define the first draft ('literal translation') that would lead to a fully-fledged final version. What is more, the foreign text rendered into Spanish - labelled 'translation', 'version' or 'adaptation' — was not necessarily presented for censorship or even published under the name of the person who undertook the transfer from one language to another.

Professional translators like Méndez Herrera usually lacked the means, the power, or even the will to exercise their rights, and were forgotten once the translation commission was over. The fact is that most of the actual names of the professionals who rendered foreign plays into the target language are usually unknown to us today and the few that may be identified with the actual process of translation can only be traced using sources such as censorship archives since 'translator' and 'adaptor' were required fields on application forms. When compiling catalogues of translations from archives such as the AGA, 'translator' or 'adaptor' (or assumed translator or adaptor) then stands for the name identified along with that of the original writer as author of the Spanish version, and as 
such is filed in censorship reports and manuscripts, ${ }^{3}$ or in published versions of translated plays.

In the role of 'assumed translators' we find actors, directors, playwrights and professional translators. Any of them taken individually or as a group could be the subject of a study on the history of theatre translations in Spain. However, in addition to the directing or acting for which they were better known, their roles as translators-adaptors when considered in the light of their 'original' text production may contribute to a deeper knowledge of the history of Spanish theatre (original and translated) in general (Merino-Álvarez, 2012, pp. 135-136).

\section{Méndez Herrera's translations}

Méndez Herrera was a professional translator who produced versions of plays by Shakespeare (for which he was awarded the Spanish National Prize for Translation in 1962) and works by various playwrights (Albee, Miller, Williams). His name can be traced in the censorship files from the early 1940s until the end of the 1970s and the study of his career as a theatre translator could illustrate the whole period of the Franco dictatorship and would no doubt merit an entire book.

\footnotetext{
${ }^{3}$ It is not unusual to find in a given censorship record different names filed under 'translator' for the same 'translation'. For example, the Spanish text of Albee's The Zoo Story was first filed as translated by García-Rey but all the subsequent manuscripts filed in the AGA and even the 1991 publication of the play were under the name of William Layton (Merino-Álvarez, 2005). Other cases gave rise to confrontation between the actual translator and the person named as author of the 'version' for the stage. Canta gallo acorralado (Cock-a-Doodle Dandy) by O'Casey was filed by the censorship office as a version by playwright Antonio Gala. The translator, Ana Antón-Pacheco, complained to the authorities and the theatre company about the use of her text without prior permission.
} 
Very much in tune with the invisible nature of the translation process, Méndez Herrera's work as a translator has not been studied, and virtually no reference to him can be found other than for his role as translator of authors like Dickens, Shakespeare, Stevenson or Priestley. Only recently has his name been quoted in newspaper articles in relation to his son, Alberto Méndez, author of Los girasoles ciegos, a successful novel adapted for the screen. We know from these brief references that he worked for the FAO (U.N. Food and Agricultural Organization), and led an exile's life in Rome (Valls, 2005) working as a translator for various Spanish publishing houses.

Méndez Herrera's career as theatre translator was long and fruitful, starting before the Civil War and continuing afterwards from his Roman exile. His command of foreign languages led him to make a living out of translation and to have close links with Spanish culture. He was well respected as a professional translator and this unusual position in Spanish theatre culture meant that his name was systematically acknowledged in reports, manuscripts and published translations. As a theatre translator his name can be found in 18 entries in the AGA theatre database from 1941 until 1977, and over twenty translations by Méndez Herrera have been recorded in TRACE-theatre catalogues, compiled from direct consultation of censorship documents, of both published plays and scripts for theatrical productions (see Appendix).

During the censorship under the Franco regime, Méndez Herrera translated many controversial plays. His version of A Streetcar Named 
Desire was first banned in 1950 but the successive rewritings submitted to the censor (the first approval was granted in 1951) were instrumental in introducing Williams' plays and contentious topics, particularly homosexuality, to Spanish stages (Pérez López de Heredia, 2004, pp. 162169). In the 1960s Méndez Herrera's translations of Shaw's Pygmalion and Miller's After the Fall and The Price reached Spanish stages, as did his translations of plays by Fabbri and Pirandello and other commercial hits. ${ }^{4}$

\section{Who's afraid of Virginia Woolf?}

Although the entire corpus of Méndez Herrera's translations would merit a detailed study, we will focus on his translation of Edward Albee's play. The actual title, Who's afraid of Virginia Woolf? (¿Quién teme a Virginia Woolf?), is not recorded in the AGA theatre database, and could only be identified and documented through direct sampling in the censorship archives. This polemical play reached the stage (16 February 1966, Teatro Goya, Madrid) after a complex process of censorship in the heyday of the 1960s Spanish ‘apertura' or policy of openness (Muñoz Cáliz, 2006).

\footnotetext{
${ }^{4}$ The Spanish translation of Lawrence Roman's Under the Yum Yum tree was first filed as record number 267-61, and attributed to Méndez Herrera. In later exchanges of documents with censorship authorities it was presented as 'adapted' by actress Catalina Montes, who along with Roman's representative in Spain, Andrés Kramer, fought a long and bitter censorship case in which the name of the translator, a much less powerful figure in the theatre system, was no longer mentioned. The main issue at stake was pre-marital relations and the play was considered 'too strong'. After several attempts to have the script approved and endless negotiations with the censors (many a letter started "with every wish to cooperate with the censor"), the final authorization was granted with restrictions (audiences over 18 with cuts, 25 April 1962).
} 
The first petition for a stage production of Albee's Who's afraid of Virginia Woolf? (censorship AGA number 215/65) was signed by José Osuna (8 November 1965), director of the production scheduled for the Teatro Marquina. The name of the translator is specified along with the representative of the author in Spain, Andrés Kramer. The play was evaluated by the usual selection of three censors, in this case Fr. Artola, Mr. Baquero and Mr. Mostaza. They all deemed that the play could be authorized and classified 2, for audiences over 18, but a series of cuts were proposed, mostly isolated words and expressions considered to contain excessively strong language. ${ }^{5}$

The religious censor, Fr. Artola, proposed around twenty-six cuts in over twenty pages of the manuscript on expressions deemed 'indecent', 'extreme' and 'harsh', such as 'mierda' (shit, 'screw you' in the original), 'testículo derecho' (right testicle, 'right ball' in the original) or 'montar a la anfitriona' (mount the hostess).

One of the censors, Mr. Mostaza, clearly states in his report that the script could easily be approved for Teatros de Cámara y Ensayo (Club Theatres) with no modifications, but that a commercial stage would require the text to be trimmed (he actually suggests thirteen deletions of words and short expressions in the manuscript). Approval for Club Theatres usually implied no cuts, since the restriction of smaller audiences

\footnotetext{
${ }^{5}$ Quotes in this section, either censors' comments or expressions from the manuscript have been taken from AGA record 215/65, which consists of sixty pages of brief non-paginated documents. All quotations from the records consulted are in our translation.
} 
and one-night productions was deemed enough. Monléon (1971, p. 70) points out that club theatre performances were the back door that enabled the introduction of new topics to Spanish commercial stages and favoured the creation of a "leftish theatre".

Censor (and theatre critic) Mr. Baquero did not propose specific cuts, but rather referred to "limitations", being inclined to find a way to authorize the play with restrictions. The nature of these limitations could be geographical (approval for Madrid only), or a matter of age (over 18). Adaptations and modifications to tone down the language of the play and make it "less crude" were recommended. Another measure proposed to accommodate the text was the addition of a note about the "corrosive tone" of the original play in the theatre programme for the production. Success abroad and the prize awarded to the American production in the 1962-63 season were used as counter-arguments that would favour authorization. Baquero backs up his report quoting the official theatre censorship norms (published in the Official Gazette-BOE, 1964) that could be used to strike a balance in the final decision. He claims that while norms 8 and 18 recommend banning plays that justify divorce, adultery, unlawful sexual relations or prostitution, or present a "lascivious climate", norm 6 might be quoted to justify "degradation" on stage, and even risk the spectators' adverse reaction to evil behaviour if a proper moral conclusion is reached (Informe, 1964, p. 18).

The case for authorizing Albee's play required additional reports from the rest of the members of the theatre censorship Board, who were 
summoned to a general meeting or Pleno. Among the seven reports issued is Father Fierro's, which defined the play as "harsh, disagreeable, but not immoral". Another censor, Mr. de la Torre, representative of the Spanish Society of Authors (SGAE), saw no serious objections, but pointed out a few words that could be modified while praising the overall quality of the play and the "exemplary" ending. In his report, he mentions polemical plays that had previously been approved (Miller's A View from the Bridge, or Williams' A Streetcar Named Desire) adding that the language in those was no less dangerous or daring. Mr. Barceló, theatre critic in the Catholic newspaper El Alcázar, thought that adapting the language would not temper the atmosphere of the play. He seemed to be concerned about the "receptivity of our audiences", and for him it was a question of either "full approval" or an "outright ban". The reports were discussed in the plenary meeting of the theatre censorship Board (16 November 1965) and the play was classified "authorized for over 18" with cuts and adaptations. The quality of the text and the fact that it had reached the main international stages were taken as strong arguments in favour. The cuts agreed by the Board were a small selection of those proposed individually by censors. ${ }^{6}$

\footnotetext{
${ }^{6}$ The certificate granting permission for the stage production of Who's afraid of Vriginia Woolf? (¿Quién teme a Virginia Woolf?) states the following cuts and modifications. Cuts (act I, pages 1, 7, 8, 46, 47, 55, 61; act II pages 30, 43, 49 and 50): me cago en, mierda, acostarse, mala leche, saliva, escroto, te violaré, hacer puñetas, hacérselo encima, hija de su madre, testículo derecho, marica, el trasero, recuperé mi virginidad, hijo de puta, montar a la anfitriona. Adaptations (act I, pages 7, $8,11,14,32,38,54,59$ and 61 ; act II pages 3, 16, 25, 44 and 50): mala leche > mala uva, vete a la
} 
Along with censors' reports and the minutes of the Board's meeting, we find other documents filed in censorship record 215/65 once rehearsals were under way. A letter sent by director José Osuna (registered 1 February 1966) states that "the suggested changes" had been followed in the rehearsals and that "all expressions that could have harmed the feelings of the average spectator (violar/rape, testículo/testicle, hijo de puta/son of a bitch, escroto/scrotum) had been replaced by equivalent words with "the same intention but weaker effect". He says that words and expressions which are not "intrinsically bad, just bad taste" (mierda/shit or vete a hacer puñetas/go to hell) were being retained in the stage production rehearsals, since they were the linguistic means of establishing the psychology of the characters. On the stage, the director argues, they are matter-of-fact, habitual ways for the characters to express themselves. The Board did not approve these changes and ratified the original restrictions. ${ }^{7}$ Osuna sent a second lengthy letter, addressed to the Director General, in an attempt to have the banned expressions restored, but this petition was also rejected. The Director

mierda > vete a tomar viento fresco, vete a hacer puñetas > vete a hacer gárgaras, su testículo derecho > su riñón derecho. The manuscript, marked with these cuts and modifications, was used by the censors in charge of reviewing dress rehearsals, and is most probably the text found in the AGA record consulted for this contribution.

${ }^{7}$ The manuscript, filed in the record, shows that the banned expressions and modifications Osuna was trying to restore were retained. Among others we find: 'vete a hacer puñetas' (go to hell), crossed out and substituted by the lighter 'vete a hacer gárgaras'; 'testículo derecho' (right testicle) changed to 'riñón derecho' (right kidney); or 'hijo de puta' substituted by 'hijo de Satanás' (Satan's son). 
General mentions the letter in his Memoirs (a day to day account of his activity as Head of the Theatre and Film Censorship Directorate): "Osuna requests permission for a few more 'shits' to adorn Albee's Who's Afraid of Virginia Woolf?" (García Escudero, 1978, p. 194, our translation). García Escudero compares Albee's play to the polemical The Purple Dress of Valentine by F. Sagan: "It is surprising that our society-and not just the pious sector - still has that puritan attitude, they find scandal in what is said and not in what is done. Of course Virginia Woolf is moral but Valentine is not" (1978, p. 199, our translation). Appearances, double morality and references to strong language or value judgements on plays (immoral vs strong) are frequent topics in García Escudero's Memoirs (1978).

Director José Osuna was officially informed (8 February 1966) that his second petition was not accepted and the restrictions of the authorization were maintained. The first Guía de Censura (blue cardboard certificate used as proof of authorization for production), specifying the modifications agreed by the Board was issued on 12 February $1966 .^{8}$ The dress rehearsal was reviewed by the censorship inspectors, who filed positive reports ("no incidents", 14 February 1966). The play's premiere took place on 16 February 1966 at Teatro Goya, Madrid, where it became a box-office success. $^{9}$

\footnotetext{
${ }^{8}$ The second Guía was filed on 13 January 1968, and two performances by Carátula Theatre Group (Canary Islands) were permitted.

${ }^{9}$ A petition to have the play on a tour of the provinces was sent on 26 July 1966 and a limited route was approved with the same restrictions (audiences over 18 with cuts). The play was approved
} 
The premiere (Llovet, 1966) brought about strong reactions in the press, most notably the editorial published in the Catholic newspaper EI Diario Regional entitled "inexplicable show", which triggered the reaction of the Director General García Escudero who wrote a letter to be published in the newspaper and dated 21 March 1966, addressed to the director of El Diario Regional (Pérez López, 1992, p. 848) and filed in the record along with a copy of the note sent to the representative of the Ministry for Information and Tourism in Valladolid, asking him to make sure the matter was managed with diligence. The letter is a detailed account of the reaction to the premiere of Who's afraid of Virginia Woolf?, with quotes from press reviews by the leading Madrid theatre critics. García-Escudero argues that the editorial in El Diario Regional is biased, since only negative reactions are quoted. He cites whole sentences from the reviews, aiming to show that the overall impression of theatre critics was balanced. He goes further and informs the reader that the play was passed with the votes of the majority of the censorship Board.

This was not the first time the Director General had to explain the decisions of the censorship Board. In 1964 he wrote a fifty-page report (Informe, 1964) in answer to a series of ecclesiastical documents that harshly attacked the apertura or open policy of the Ministry for 
Information and Tourism team, working under Fraga as Minister (1962-69) and García Escudero as Director General for Film and Theatre (1962-67).

Both his Memoirs (1978) and the unpublished Report (Informe, 1964) are sources that add a new dimension to the information filed in the AGA archives in relation to Theatre Censorship in the 1960s. García Escudero is conscious of his role as censor, but he is also aware of his difficult position as "censored censor". When writing about the frictions between ministerial authorities and prominent playwrights like Buero Vallejo, who often criticized the limitations imposed by censorship, Garcia Escudero reflects: "I could have told him [Buero Vallejo] ${ }^{10}$ the story of the censored censor and that of the three types of censorship: the one he speaks about and which I represent; another, the social censorship which I suffer; and a third type, which nobody speaks about: that of the businessmen and the industry, the worst type, and he and I have to face it equally" (1978, p. 223). The negotiations on cuts and modifications that led to the Spanish stage production of Albee's play had their counterparts elsewhere. In the 1962 Broadway premiere, the play's running time was reduced by fifteen minutes (Bottoms, 2000, p. 34). Other productions across the US

\footnotetext{
${ }^{10}$ Arcadio Baquero, theatre-critic and member of the Board from 1963 to 1967, in an interview published shortly before he died, said: "when I was asked to become a member of the Censorship Board, before giving an answer I asked my good friends in the theatre profession and they all advised me to accept. They said that censorship could help them enormously. I do think that was the case" (Muñoz Cáliz, 2004, p. 19, our translation). Among these friends was Buero Vallejo who had turned down proposals to become member of the Board since he thought any official relation with the authorities could undermine his position as critical playwright. When asked about the 1960s open policy, Baquero states that García Escudero's period was indeed open, adding that among the members of the Board were many liberals and well-known theatre professionals (Muñoz Cáliz, 2004, p. 19, our translation).
} 
accommodated modifications suggested by the local authorities. The London 1963 production had to face the warnings and more than sixty cuts proposed by the Lord Chamberlain's office (Bottoms, 2000, pp. 44-45). But it was the US film adaptation that brought about the strongest clamour against the Production Code of the Motion Picture Association of America. Written and run by Catholics, the Code had been instrumental in eliminating homosexuality from the film version of Cat on a Hot Tin Roof, but allowed the film adaptation of Albee's drama. The United States regulatory committee did not manage to censor its "gritty language" which "brazenly violated the rigid guidelines that had dictated the content of American movies since 1934" (Lord, 2011). When the National Catholic Office for Motion Pictures saw the play's "redeeming value" the film was classified and exhibited for adults over 18 (Bottoms, 2000; Leff, 1981; Quicke 2010) in 1966.

The American censors' battle and the arguments used to propose cuts in the film version of Albee's play were in essence no different from those of their Spanish or British counterparts, ${ }^{11}$ and foul language was once more gauged against the play's redeeming ending. Against all odds and all censoring bodies, whether American or Spanish, Albee's play was a world success in the 1960s which helped overcome restrictive barriers (Lavery \& MacGuire, 2013; Semonche, 2007), because the times seemed to be changing on both sides of the Atlantic.

\footnotetext{
${ }^{11}$ Expressions like 'goddam', 'screw you', 'bugger', 'plowing pertinent wives', 'hump the hostess' or 'mount her like a goddam dog' that offended censors' ears in America were basically the same that had been marked by Spanish and British censors for deletion or modification.
} 


\section{Conclusion}

Albeit working under a totalitarian regime, Spanish theatre censorship was, in the way it functioned and under the strong influence of religious morality, as restrictive in sensitive cases as its counterparts in countries which enjoyed elected governments and a long democratic tradition. Censoring bodies in the 1960s were strongly influenced by religious organizations, and sexual morality was often at stake when playwrights and filmmakers tried to oppose established norms. The censorship case of Who's afraid of Virginia Woolf? helped change attitudes: it did introduce foul language and a shocking view of marital relations on the stage (with cuts in Spain and the UK), and adapted to the big screen, it opened the way for a new classification system based on age restrictions in the US. The very fact that the play was at the centre of public controversies gained its author worldwide fame, and the directors and producers in various countries benefited from the publicity as well.

The success of Who's afraid of Virginia Woolf?, boosted by the echoes of the censoring process, made Albee an extremely popular author in Spain. The 1966 production of his play was a clear sign of change, confirming that a relaxation within the governmental structure in charge of censorship was at work. Caught in a flux of resistance and reaction, García Escudero and his team managed to restructure the Board for film and theatre censorship and to publish the norms and select censors who were more professional and less political. Constant attacks came from left and right, but the basis for a transition to a renewed 
governmental structure was laid down. The old moral code that

reactionary forces still tried to maintain was overcome by the reality of everyday life in the 1960s. Spanish theatre producers imported foreign plays through translation to spearhead change on stage, knowing that censorship was more lenient on the 'foreign', but once landmark productions like Who's afraid of Virginia Woolf? broke the ice, native products could follow suit.

\section{References}

Bandín Fuertes, E. (2007). Traducción, recepción y censura de teatro clásico inglés en la España de Franco. Estudio descriptivo-comparativo del Corpus TRACEtci (1939-1985) [Translation, reception and censorship of English classical theatre in Franco's Spain. A descriptive-comparative study of TRACEtci (1939-1985) corpus] (Unpublished doctoral dissertation). University of León, León (Spain).

Bandín Fuertes, E. (2011). Las páginas olvidadas del teatro español: traducciones y adaptaciones del teatro clásico inglés durante el franquismo [The forgotten pages in Spanish theatre: translations and adaptations of classical English theatre under Franco's rule]. Represura. Revista de Historia Contemporánea española en torno a la represión y la censura aplicadas al libro 7. Retrieved from http://www.represura.es/.

Bottoms, S.J. (2000). Albee: Who's afraid of Virginia Woolf? Cambridge: Cambridge University Press.

Delgado, M \& D. T. Gies (Eds.), A history of theatre in Spain. Cambridge: Cambridge University Press.

García Escudero, J. M. (1978). La primera apertura. Diario de un director general. La larga batalla de la censura en cine y teatro [The first opening. Memoirs of a director general. The long battle for cinema and theatre censorship.]. Barcelona: Planeta.

Gutiérrez Lanza, C. (2011). Censors and censorship boards in Franco's Spain (1950s-1960s): an overview based on the TRACE cinema catalogue. In D. Asimakoulas \& M. Rogers (Eds.), Translation and Opposition (pp. 305-320). Bristol: Multilingual Matters.

Informe sobre la Censura Cinematografica y Teatral [Report on Cinema and Theatre Censorship] (1964). Ministerio de Información y Turismo. 
Dirección General de Cinematografía y Teatro [Ministry for Information and Tourism. General Directorate for Cinema and Theatre] Unpublished.

Lavery, D. \& N. McGuire Roche. (2013) Hollywood's Who's afraid of Virginia Woolf?: Breaking the code. In W. R. Bray \& R. Barton Palmer (Eds.), Modern American Drama on Screen (pp. 187-202). Cambridge: Cambridge University Press.

Leff, L. (1981) Play into Film: Warner Brothers' Who's afraid of Virginia Woolf? Theatre Journal, 33, 453-466.

Llovet, E. (1966, February 17). Estreno de ¿Quién teme a Virginia Woolf? en el Goya [Premiere at Goya of Who's afraid of Virginia Woolf?]. ABC, p. 93. Retrieved from http://hemeroteca.abc.es.

London, J. (1997). Reception and Renewal in Modern Spanish Theatre: 19391963, Leeds: W. S. Maney \& Son Ltd, Modern Humanities Research Association.

London, J. (2012). Theatre under Franco (1939-1975): Censorship, playwriting and performance. In M. Delgado \& D. T. Gies (Eds.), A history of theatre in Spain (pp. 341-371). Cambridge: Cambridge University Press.

Lord, M. G. (2011, March 30). How Elizabeth Taylor's 'sexual intensity' helped tear down the production code, The Hollywood Reporter. Retrieved from http://www.hollywoodreporter.com/

Merino-Álvarez, R. (1994). Traducción, tradición y manipulación. Teatro inglés en España 1950-90 [Translation, tradition and manipulation. English theatre in Spain 1950-90]. León: University of León / University of the Basque Country.

Merino-Álvarez, R. (2005). La investigación sobre teatro inglés traducido inglés-español, 1994-2004 [Research on theatre translation EnglishSpanish], Cadernos de Literatura Comparada, 12/13, 99-119.

Merino-Álvarez, R. (2007). La homosexualidad censurada: estudio sobre corpus de teatro TRACEti (desde 1960) [Censored homosexuality: studies on TRACEti corpus since 1960]. In R. Merino-Álvarez (ed.), Traducción y censura en España (1939-1985). Estudios sobre corpus TRACE: cine, narrativa, teatro (243-286). Bilbao: Universidad del País Vasco/Universidad de León. Retrieved from http://hdl.handle.net/10810/10169.

Merino-Álvarez, R. (2010). Building TRACE (translations censored) theatre corpus: some methodological questions on text selection. In M. Muñoz \& C. Buesa (Eds.), Translation and Cultural Identity: Selected Essays on Translation and Cross-Cultural Communication (pp. 116138). Newcastle: Cambridge Scholars Publishing. 
Merino-Álvarez, R. (2012). A historical approach to Spanish theatre translations from censorship archives. In I. García-Izquierdo \& E. Monzó (Eds.), Iberian Studies on Translation and Interpreting (pp. 123140). Oxford: Peter Lang.

Monleón, J. (1971). Treinta años de teatro de la derecha. Barcelona: Tusquets.

Muñoz Cáliz, B. (2004). Entrevista a Arcadio Baquero Goyanes, Miembro de la Junta de Censura Teatral entre 1963 y 1967 [Interview. Arcadio Baquero Goyanes, member of the Theatre Censorship Board between 1963 and 1967], Las puertas del drama. Revista de la Asociación de Autores de Teatro, AAT, Libertad de Expresión I. 18, 1721.

Muñoz Cáliz, B. (2005). El teatro crítico español durante el franquismo visto por sus censores. Madrid: Fundación Universitaria Española.

Muñoz Cáliz, B. (2006). Expedientes de la censura teatral franquista, Madrid: Fundación Universitaria Española.

Muñoz Cáliz, B. (2008). Los expedientes de la censura teatral como fuente para la investigación del teatro español contemporáneo. Teatro (Revista de Estudios Escénicos), 22, 27-40.

O'Leary, C. (2005). The theatre of Antonio Buero Vallejo: ideology, politics and censorship. Woodbridge: Tamesis.

Pérez López de Heredia, M. (2004). Traducciones censuradas de teatro norteamericano en la España de Franco (1939-1963) [Censored translations of US theatre in Franco's Spain (1939-1963)]. Bilbao: University of the Basque Country.

Pérez López de Heredia, M. (2005). Inventario de las traducciones censuradas de teatro norteamericano en la España de Franco (19391963) [Catalogue of censored US theatre translations in Franco's Spain (1939-1963)]. In R. Merino-Álvarez, J. M. Santamaría \& E. Pajares (Eds.), Trasvases culturales: literatura, cine y traducción, 4 (pp. 97-112). Bilbao: University of the Basque Country. http://hdl.handle.net/10810/10537

Pérez López, P. (1992). Católicos, políticos e información: Diario Regional de Valladolid, 1931-1980. Valladolid: Universidad de Valladolid.

Quicke, A. (2010) The era of censorship (1930-1967). In J. Lyden (Ed.), The Routledge companion to religion and film (pp. 32-51). Abingdon: Routledge.

Rabadán, R. (ed.) (2000). Traducción y censura inglés-español, 1939-1985. Estudio Preliminar [Translation and censorship English-Spanish, 1939-1985. Preliminary Study.]. León: University of León. 
Santoyo, J.C. (1983). La cultura traducida. Lección inaugural del curso 198384 [Translated culture. Inaugural lecture, academic year 1983-84]. León: University of León.

Semonche, J.E. (2007) Censoring sex: A historical journey through American media. Plymouth: Rowman \& Littlefield.

Valls, F. (2005, October 15). Alberto Méndez, o la dignidad de los vencidos [Alberto Méndez or the dignity of the defeated], El País. Retrieved from http://www.elpais.com. 


\section{Appendix: Translations by José Méndez Herrera (Sources: AGA \& TRACE-theatre)}

\begin{tabular}{|l|l|l|l|}
\hline Title of playtext & Author & $\begin{array}{l}\text { Record number } \\
\text { /year submitted }\end{array}$ & Approved \\
\hline Una visita en la noche & Casas Bricio, Antonio & $2575 / 41$ & 1941 \\
\hline El angelus & Martín Alonso, M. & $3815 / 43$ & 1944 \\
\hline En la hora del diablo & Martín Alonso, M. & $0734 / 45$ & 1947 \\
\hline Un tranvía llamado Deseo & Williams, Tennessee & $0217 / 50$ & 1951 \\
\hline La heredera & Goetz, Augustus y Ruth & $129 / 51$ & 1952 \\
\hline Cocktail Party & Eliot, T. S. & 28.02 .52 & 1952 \\
\hline El cero y el infinito & Kingsley, Sidney & $164 / 52$ & 1952 \\
\hline Cuento de invierno & Shakespeare, William & $056 / 53$ & 1953 \\
\hline Un tranvía Ilamado Deseo & Williams, Tennessee & $217 / 57$ & 1957 \\
\hline El árbol del amor (provisional) & Roman, Lawrence & $267 / 61$ & \\
\hline Mi querido embustero & Kilty, Jerome & $313 / 61$ & 1962 \\
\hline La sonata a Kreutzer & Watt, Hannah & $0002 / 63$ & 1964 \\
\hline Pigmalión & Shaw, George Bernard & $166 / 63$ & 1963 \\
\hline La noche de la iguana & Williams, Tennessee & $7 / 64$ & 1965 \\
\hline Robo en el Vaticano & Fabbri, Diego & $0030 / 64$ & 1964 \\
\hline El gorro de cascabeles & Pirandello, Luigi & $0123 / 64$ & 1964 \\
\hline Después de la caída & Miller, Arthur & $0237 / 64$ & 1966 \\
\hline ¿Quién teme a Virginia Woolf? & Albee, Edward & $215 / 65$ & 1966 \\
\hline La piedad en noviembre & Brusati, Franco & $0206 / 66$ & 1966 \\
\hline Las troyanas & Euripides & $0196 / 69$ & 1974 \\
\hline El precio & Miller, Arthur & $0011 / 70$ & 1970 \\
\hline Un enemigo del pueblo & lbsen, Henrik & $403 / 71$ & 1973 \\
\hline Los lúnaticos & Middleton, Thomas & $0370 / 72$ & $0313 / 73$ \\
\hline Hamlet & Shakespeare, William & $0417 / 77$ & \\
\hline Viernes día de libertad & Claus, Hugo & & \\
\hline & & \\
\hline
\end{tabular}




\section{Abstract}

Over the last decade, Spain's censorship records have been used by translation studies scholars as the main source to reconstruct the history of translated culture. Censorship archives are virtually the only source of information to research the history of theatre translations in Spain, since they provide access to materials that range from contextual information to actual manuscripts (from draft versions to final censored texts). This contribution will provide a glimpse into the history of theatre translations in the 1960s, a period of political openness from within the Ministry in charge of theatre censorship and of intense activity on Spanish stages. Using textual and contextual evidence gathered from Spanish censorship archives, the actual process that led to the 1966 stage production of Albee's Who's Afraid of Virginia Woolf? will help illustrate how play scripts were evaluated when submitted to the censors' ideologicallybiased scrutiny and to what extent ideological manipulation was forced into the production script. Such evidence shows that foreign plays were integrated into Spanish theatre through translation and adaptation. It also reveals the role of censors, stage directors and professional translators in the censorship process that can be traced from the actual records.

Keywords: censorship, ideology, theatre translation, history of Spanish theatre

\section{Bionote}

Professor Raquel Merino (http://orcid.org/0000-0002-3772-0461) holds a Chair of Translation at the University of the Basque Country. She has coordinated the TRACE (translation and censorship) Project and she is currently Principal Investigator of the TRALIMA (Translation, Literature and Audio-visual Media) consolidated research group funded by the Basque Government (www.ehu.es/tralima).

Her publications deal with the history of translated theatre in Spain and translation and censorship. 